\title{
FAKTOR-FAKTOR YANG BERHUBUNGAN DENGAN PEMBERIAN ASI EKSKLUSIF DI KELURAHAN SAWAHAN WILAYAH KERJA PUSKESMAS ANDALAS PADANG TAHUN 2017
}

\author{
Rischa Hamdanesti ${ }^{1}$, Mela Sari ${ }^{2}$ \\ ${ }^{1}$ STIKes Alifah, Padang 25000 \\ Email: deary_cha@yahoo.co.id@yahoo.co.id \\ ${ }^{2}$ Sekolah Tinggi Ilmu Keperawatan Alifah Padang \\ Email: stikes_alifah@yahoo.com
}

\begin{abstract}
ABSTRAK
ASI eksklusif adalah makanan yang terbaik bagi bayi pada 6 bulan pertama kehidupannya. Cakupan pemberian ASI eksklusif terendah di Wilayah Kerja Puskesmas Andalas adalah di Kelurahan Sawahan yaitu 45\%. Penelitian ini bertujuan untuk mengetahui faktor-faktor yang berhubungan dengan pemberian ASI eksklusif di Kelurahan Sawahan Wilayah Kerja Puskesmas Andalas Padang tahun 2017.

Jenis penelitian analitik, dengan pendekatan cross sectional, Penelitian dilaksanakan di Kelurahan Sawahan Wilayah Kerja Puskesmas Andalas Padang tahun 2017. Pengumpulan data tanggal 02 - 12 Agustus 2017. Populasi pada penelitian ini adalah semua ibu yang mempunyai bayi usia 7-12 bulan di Kelurahan Sawahan Wilayah Kerja Puskesmas Andalas Padang tahun 2017. Sampel di ambil secara total sampling sebanyak 61 orang. Pengambilan data dengan kuesioner. Analisa data dilakukan secara univariat dalam bentuk distribusi frekuensi dan bivariat menggunakan uji Chi Square.

Disimpulkan bahwa ada hubungan pengetahuan, tingkat pendidikan, pekerjaan dengan pemberian ASI Eksklusif. Disarankan kepada pusat pelayanan kesehatan petugas puskesmas Andalas padang tidak mempromosikan susu formula, memberikan informasi yang tepat tentang ASI dan seputar kegiatan menyusui, serta memberikan semangat dan dorongan agar para ibu memberikan ASI eksklusif kepada bayi mereka.
\end{abstract}

\section{Kata Kunci: ASI Ekslusif, Pengetahuan, Pekerjaan Tingkat Pendidikan}

\begin{abstract}
Abstrack_Exclusive breastfeeding is the best food for babies in the first 6 months of life. The lowest coverage of exclusive breastfeeding in the Working Area of Andalas Health Center is in Sawahan Village, $45 \%$. This study aims to determine the factors associated with exclusive breastfeeding in Sawahan Village Work Area Puskesmas Andalas Padang in 2017.

Method_The type of analytic research, with cross sectional approach, was conducted in Sawahan SubDistrict of Andalas Puskesmas Working Area in 2017. Data collection dated 02 - 12 August 2017. The population in this study were all mothers of 7-12 month old infants in Sawahan Kelurahan Kelurahan Work Puskesmas Andalas Padang in 2017. Samples taken in total sampling of 61 people. Data collection with questionnaire. Data analysis was done univariat in the form of frequency distribution and bivariate using Chi Square test.

Conclusion_It is concluded that there is a relationship of knowledge, level of education, work with Exclusive breastfeeding. It is recommended that health centers at the health center of Andalas Padang do not promote formula milk, provide appropriate information about breastfeeding and around breastfeeding activities, and encourage and encourage mothers to exclusively breastfeed their babies.
\end{abstract}

Keywords: Breast Feeding Exclusive, Knowledge, Education Level Work 


\section{PENDAHULUAN}

Pertumbuhan dan perkembangan bayi dapat dilihat dari seiring dengan pertambahan umur, tahapan yang dilalui sesuai dengan umur mereka, ditandai lewat kemajuan aktivitas yang diperlihatkannya. Bayi yang diberikan makanan tambahan semi padat maupun padat pada usia sebelum 6 bulan maka akan berbahaya bagi bayi hal tersebut akan mempengaruhi tumbuh kembang bayi, bayi yang diberikan susu formula lebih sering menderita kurang gizi salah satu faktor penyebab tingginya angka kematian bayi adalah status gizi bayi. Status gizi bayi dapat ditingkatkan melalui ASI secara eksklusif selama 6 bulan, guna dapat menurunkan angka kematian bayi di Indonesia setiap tahunnya (Fikawati, 2015).

Angka kematian bayi di Dunia masih tergolong tinggi. Berdasarkan data UNICEF, angka kematian bayi di dunia mencapai lebih 10 juta kematian. Dari 10 juta kematian bayi, hampir $90 \%$ kematian bayi terjadi di negara-negara berkembang. (WHO, 2005). Sedangkan Angka kematian bayi di Indonesia dari tahun ke tahun sudah mengalami penurunan, menurut hasil SDKI 2007 dari 34/1000 Kelahiran Hidup menjadi 32/1000, pada tahun 2012 (SDKI, 2012). Sedangkan di Sumatra Barat angka kematian bayi mengalami penurunan dari 47/1000 Kelahiran Hidup pada tahun 2007 menjadi 27/1000, pada tahun 2012 (Dinas Kesehatan, 2015).

Pemberian ASI eksklusif di dunia masih rendah. Berdasarkan data dari United Nations Children's Fund (UNICEF) hanya 39\% bayi di bawah usia 6 bulan yang mendapatkan ASI eksklusif di seluruh dunia, angka tersebut juga tidak mengalami kenaikan pada tahun 2015, yaitu hanya $40 \%$ keberhasilan pemberian ASI eksklusif di seluruh dunia. Cina yang merupakan salah satu negara dengan jumlah populasi penduduk yang cukup besar di dunia hanya memiliki angka keberhasilan ASI eksklusif sebesar 28\%. Negara lain yaitu Tunisia memberikankabar buruk dalam waktu satu dekade terakhir, dimana persentase pemberian ASI eksklusif mengalami penurunan sangat drastis dari $45,6 \%$ turun menjadi $6,2 \%$, sedangkan negara-negara yang menduduki posisi 3 angka pemberian ASI eksklusif terendah dunia menurut data UNICEF antara lain Somania, Chad, dan Afrika Selatan (Depkes RI, 2012). Di Indonesia cakupan pemberian ASI eksklusif pada bayi usia 0-6 bulan dari tahun ketahun pemberian ASI eksklusif mengalami penurunan dan peningkatan, pada tahun 2012 mengalami penurunan sebesar $12,9 \%$ menjadi 48,6\% dan pada tahun 2013 mengalami peningkatan sebesar 5,7\% menjadi 54,3\% pada tahun 2014 relatif turun menjadi $52,4 \%$ sedangkan target program pada tahun 2014 sebesar 80\% (Kementrian Kesehatan RI, 2015).

Di Sumatera Barat cakupan pemberian ASI eksklusif tiga tahun terakhir, dimana pada tahun 2013 cakupan pemberian ASI eksklusif adalah 67,4\% dengan target $75,0 \%$, tahun 2014 cakupan pemberian
ASI eksklusif adalah 72,5\% dengan target $80,0 \%$, dan cakupan ASI eksklusif pada tahun 2015 adalah $72,8 \%$ dengan target $83,0 \%$. Hal ini nenunjukan bahwa bahwa Provinsi Sumatera Barat belum mencapai target program nasional (Dinas Kesehatan, 2015).

Penyebab faktor kurangnya pemberian ASI eksklusif adanya pengetahuanyang rendah tentang manfaat dan tujuan pemberian ASI eksklusif. Kemungkinan pada saat pemeriksaan kehamilan mereka tidak memperoleh penyuluhan intensif tentang ASI eksklusif, kandungan dan manfaat ASI, dan kerugian jika tidak memberikan ASI eksklusif. Serta dengan faktor pendidikan makin tinggi pendidikan seseorang, maka makin mudah untuk menerima informasi sehingga semakin banyak pula pengetahuan yang dimiliki, sebaliknya pendidikan yang rendah akan menghambat sikap terhadap nilainilai yang baru diperkenalkan, termasuk mengenai ASI eksklusif, dan status pekerjaan pada ibu, penyebab kurangnya cakupan pemberian ASI eksklusif adalah singkatnya masa cuti hamil atau melahirkan yaitu rata-rata hanya tiga bulan keterbatasan waktu atau kesibukan kerja, sehingga menyebabkan penggunaan susu botol atau susu formula diberikan pada bayi (Kementerian Kesehatan, 2012).

Penelitian yang dilakukan oleh Ory Okawary (2015) dengan judul hubungan status pekerjaan ibu dengan pemberian ASI eksklusif di Wilayah Kerja Puskesmas Seyegan Slema Yogya karta menunjukan dari 54 responden $24 \quad(44,4 \%)$ ibu yang meninggalkan bayinya. Sedangkan Penelitian yang dilakukan oleh Tri Hartatik (2009) dengan judul hubungan tingkat pengetahuan ibu dengan pemberian ASI eksklusif di Kelurahan Gunung pati Kecamatan Gunungpati, menunjukan dari 38 responden terdapat $17(44,7 \%)$ memiliki pengetahuan kurang baik tentang ASI eksklusif.

Di Kota Padang, jumlah bayi yang mendapatkan ASI eksklusif pada tahun 2015 diKecamatan dan Puskesmas Kota Padang adalah 4,755 bayi atau cakupan ASI eksklusif adalah (72,8\%). Cakupan ASI eksklusif Puskesmas yang tertinggi adalah Puskesmas Seberang Padang, (96,6\%) sedangkan cukupan ASI yang terendah terdapat di Puskesmas Andalas yaitu (54,5\%) (Dinas Kesehatan Kota Padang, 2015).

Berdasarkan survey awal yang dilakukan oleh penelitian pada tanggal 03 Februari 2017di Dinas Kesehatan Kota Padang, didapatkan data pemberian ASI eksklusif yang terendah adalah di Puskesmas Andalas sebanyak 54,5\%, setelah dilakukan peninjauan lebih lanjut di Kelurahan Sawahan Wilayah Kerja Puskesmas Andalas Kota Padang terdapat 10 Wilayah, maka diketahui Wilayah terendah pemberian ASI eksklusif adalah tahun 2016 terdapat di Kelurahan Sawahan yaitu $45 \%$.

Berdasarkan hasil wawancara yang dilakukan oleh peneliti pada tanggal 03 Februari 2017 kepada 
Ibu yang berkunjung di Puskesmas Andalas Padang dari 10 Ibu yang mempunyai bayi usia 7-12 bulan, Dari $10 \mathrm{Ibu}$ terdapat $7 \%$ ibu tidak tahu tentang ASI eksklusif,dan dari $10 \%$ ibu 6 orang ibu bekerja, pekerjaan yang banyak dilakukan oleh ibu yaitu sebagai Wirausaha, Perguruan Tinggi, Ibu Rumah Tangga, dan lain-lain.

Hal ini menyebabkan bayi tidak sepenuhnya mendapatkan pemberian ASI eksklusif Jika hal ini dibiarkan begitu saja maka akan memiliki dampak pada bayi, yaitu bayi mudah terkena penyakit yang berhubungan dengan kekebalan tubuh.

Oleh sebab itu peneliti tertarik untuk melakukan penelitian tentang "Faktor-faktor yang berhubungan dengan pemberian ASI eksklusif di Kelurahan Sawahan Wilayah Kerja Puskesmas Andalas Padang tahun 2017".

\section{METODA PENELITIAN}

Jenis penelitian analitik, dengan pendekatan cross sectional, Penelitian dilaksanakan di Kelurahan Sawahan Wilayah Kerja Puskesmas Andalas Padang tahun 2017. Pengumpulan data tanggal $02-12$ Agustus 2017. Populasi pada penelitian ini adalah semua ibu yang mempunyai bayi usia $7-12$ bulan di Kelurahan Sawahan Wilayah Kerja Puskesmas Andalas Padang tahun 2017. Sampel di ambil secara total sampling sebanyak 61 orang. Pengambilan data dengan kuesioner. Analisa data dilakukan secara univariat dalam bentuk distribusi frekuensi dan bivariat menggunakan uji Chi Square.

\section{HASIL}

\section{A. Analisa Univariat}

Analisa Univariat menjelaskan atau mendeskripsikan karakteristik masing-masing variabel yang diteliti, dan dapat dilihat pada tabel berikut :

\section{Pemberian ASI Eksklusif}

Tabel 4.1

Distribusi Frekuensi Responden Berdasarkan Pemberian ASI Eksklusif di Kelurahan Sawahan Wilayah Kerja Puskesmas Andalas Padang tahun 2017

\begin{tabular}{ccc}
\hline $\begin{array}{c}\text { Pemberian } \\
\text { ASI Eksklusif }\end{array}$ & f & \% \\
\hline Tidak & 37 & 60,7 \\
\hline Iya & 24 & 39,3 \\
\hline Total & $\mathbf{6 1}$ & $\mathbf{1 0 0}$ \\
\hline
\end{tabular}

Berdasarkan table 4.1 didapatkan bahwa lebih dari separoh $(60,7 \%)$ responden tidak memberikan ASI eksklusif pada bayi di Kelurahan Sawahan Wilayah Kerja Puskesmas Andalas Padang tahun 2017.

\section{Pengetahuan Responden}

\section{Tabel 4.2}

Distribusi Frekuensi Responden Berdasarkan Pengetahuan di Kelurahan Sawahan Wilayah Kerja Puskesmas Andalas Padang tahun 2017

\begin{tabular}{ccc}
\hline Pengetahuan & f & \% \\
\hline Rendah & 34 & 55,7 \\
\hline Tinggi & 27 & 44,3 \\
\hline Total & $\mathbf{6 1}$ & $\mathbf{1 0 0}$ \\
\hline
\end{tabular}

Berdasarkan tabel 4.2 didapatkan bahwa lebih dari separoh $(55,7 \%)$ responden berpengetahuan rendah di Kelurahan Sawahan Wilayah Kerja Puskesmas Andalas Padang tahun 2017.

\section{Tingkat Pendidikan Responden}

Tabel 4.3

Distribusi Frekuensi Responden Berdasarkan Tingkat Pendidikan di Kelurahan Sawahan Wilayah Kerja Puskesmas Andalas Padang tahun 2017

\begin{tabular}{ccc}
\hline $\begin{array}{c}\text { Tingkat } \\
\text { Pendidikan }\end{array}$ & f & \% \\
\hline Rendah & 47 & 77,0 \\
\hline Tinggi & 14 & 23,0 \\
\hline Total & $\mathbf{6 1}$ & $\mathbf{1 0 0}$ \\
\hline
\end{tabular}

Berdasarkan tabel 4.3 didapatkan bahwa sebagian besar $(77,0 \%)$ responden mempunyai tingkat pendidikan rendah di Kelurahan Sawahan Wilayah Kerja Puskesmas Andalas Padang tahun 2017.

\section{Pekerjaan}

Tabel 4.4

Distribusi Frekuensi Responden Berdasarkan

Pekerjaan di Kelurahan Sawahan Wilayah

Kerja Puskesmas Andalas Padang tahun 2017

\begin{tabular}{ccc}
\hline Pekerjaan & F & \% \\
\hline Bekerja & 32 & 52,5 \\
\hline Tidak Bekerja & 29 & 47,5 \\
\hline Total & $\mathbf{6 1}$ & $\mathbf{1 0 0}$ \\
\hline
\end{tabular}

Berdasarkan tabel 4.4 didapatkan bahwa lebih dari separoh $(52,5 \%)$ responden bekerja di Kelurahan Sawahan Wilayah Kerja Puskesmas Andalas Padang tahun 2017.

\section{B. Analisa Bivariat}

Analisa bivariat bertujuan untuk melihat hubungan dua variabel, meliputi variabel independen yang terdiri dari pengetahuan, pendidikan dan 
pekerjaan dengan variabel dependen yaitu pemberian ASI eksklusif.

1. Hubungan Pengetahuan dengan Pemberian ASI Eksklusif

Tabel 4.5

Hubungan Pengetahuan dengan Pemberian ASI Eksklusif di Kelurahan Sawahan Wilayah Kerja Puskesmas Andalas Padang Tahun 2017

\begin{tabular}{|c|c|c|c|c|c|c|c|}
\hline \multirow{3}{*}{$\begin{array}{c}\text { Pengeta } \\
\text { huan }\end{array}$} & \multicolumn{4}{|c|}{ Pemberian ASI Eksklusif } & \multirow{2}{*}{\multicolumn{2}{|c|}{ Total }} & \multirow{3}{*}{$p$ value } \\
\hline & \multicolumn{2}{|c|}{ Tidak } & \multicolumn{2}{|c|}{$\mathbf{Y a}$} & & & \\
\hline & $\mathbf{F}$ & $\%$ & f & $\%$ & f & $\%$ & \\
\hline Rendah & 25 & 73,5 & 9 & 26,5 & 34 & 100 & \\
\hline Tinggi & 12 & 44,4 & 15 & 56,6 & 27 & 100 & 0,041 \\
\hline Total & 37 & 60,7 & 24 & 39,3 & 61 & 100 & \\
\hline
\end{tabular}

Berdasarkan tabel 4.5 didapatkan bahwa proporsi responden yang tidak memberikan ASI Eksklusif lebih banyak terdapat pada responden yang berpengetahuan rendah 25 orang $(73,5 \%)$ dibandingkan dengan responden yang berpengetahuan tinggi 12 orang $(44,4 \%)$. Hasil uji statistic (chi square) diperoleh nilai $\mathrm{p}=0,041$ ( $p<$ 0,05) maka dapat disimpulkan bahwa terdapat hubungan yang bermakna antara pengetahuan dengan pemberian ASI Ekslusif di Kelurahan Sawahan Wilayah Kerja Puskesmas Andalas Padang tahun 2017.

\section{Hubungan Tingkat Pendidikan dengan Pemberian ASI Eksklusif}

Tabel 4.6

Hubungan Tingkat Pendidikan denganPemberian ASI Eksklusif di Kelurahan Sawahan Wilayah Kerja Puskesmas Andalas Padang tahun 2017

\begin{tabular}{|c|c|c|c|c|c|c|c|}
\hline \multirow{3}{*}{$\begin{array}{c}\text { Tingkat } \\
\text { Pendidi } \\
\text { kan }\end{array}$} & \multicolumn{4}{|c|}{ Pemberian ASI Ekslusif } & \multirow{2}{*}{\multicolumn{2}{|c|}{ Total }} & \multirow{3}{*}{$p$ value } \\
\hline & \multicolumn{2}{|c|}{ Tidak } & \multicolumn{2}{|c|}{ Ya } & & & \\
\hline & $\mathbf{F}$ & $\%$ & f & $\%$ & f & $\%$ & \\
\hline Rendah & 33 & 70,2 & 14 & 29,8 & 47 & 100 & \\
\hline Tinggi & 4 & 28,6 & 10 & 71,4 & 14 & 100 & 0,013 \\
\hline Total & 37 & 60,7 & 24 & 39,3 & 61 & 100 & \\
\hline
\end{tabular}

Berdasarkan tabel 4.6 didapatkan bahwa proporsi responden yang tidak memberikan ASI Eksklusif lebih banyak terdapat pada responden yang mempunyai tingkat pendidikan rendah 33 orang $(70,2 \%)$ dibandingkan dengan responden yang mempunyai tingkat pendidikan tinggi 4 orang $(28,6 \%)$. Hasil uji statistic (chi square) diperoleh nilai $\mathrm{p}=0,013(p<0,05)$ maka dapat disimpulkan bahwa terdapat hubungan yang bermakna antara tingkat pendidikan dengan pemberian ASI Ekslusif di Kelurahan Sawahan Wilayah Kerja Puskesmas Andalas Padang tahun 2017.

\section{Hubungan Pekerjaan dengan Pemberian ASI Eksklusif}

Tabel 4.7

Hubungan Pekerjaan Dengan Pemberian ASI

Eksklusif di Kelurahan Sawahan Wilayah Kerja Puskesmas Andalas Padang tahun 2017

\begin{tabular}{|c|c|c|c|c|c|c|c|}
\hline \multirow{3}{*}{$\begin{array}{l}\text { Pekerja } \\
\text { an }\end{array}$} & \multicolumn{4}{|c|}{ Pemberian ASI Eksklusif } & \multirow{2}{*}{\multicolumn{2}{|c|}{ Total }} & \multirow{3}{*}{$\begin{array}{c}p \\
\text { value }\end{array}$} \\
\hline & \multicolumn{2}{|c|}{ Tidak } & \multicolumn{2}{|c|}{ Ya } & & & \\
\hline & f & $\%$ & f & $\%$ & $\mathbf{f}$ & $\%$ & \\
\hline Bekerja & 24 & 75,0 & 8 & 25,0 & 32 & 100 & \\
\hline $\begin{array}{l}\text { Tidak } \\
\text { Bekerja }\end{array}$ & 13 & 44,8 & 16 & 55,2 & 29 & 100 & 0,032 \\
\hline Total & 37 & 60,7 & 24 & 39,3 & 61 & 100 & \\
\hline
\end{tabular}

Berdasarkan tabel 4.7 didapatkan bahwa proporsi responden yang tidak memberikan ASI Eksklusif lebih banyak terdapat pada responden yang bekerja 24 orang $(75,0 \%)$ dibandingkan dengan responden yang tidak bekerja 13 orang $(44,8 \%)$. Hasil uji statistic (chi square) diperoleh nilai $\mathrm{p}=0,032$ ( $p$ < 0,05) maka dapat disimpulkan bahwa terdapat hubungan yang bermakna antara tingkat pendidikan dengan pemberian ASI Ekslusif di Kelurahan Sawahan Wilayah Kerja Puskesmas Andalas Padang tahun 2017.

\section{PEMBAHASAN}

A. Analisis Univariat

1. Pemberian ASI Ekslusif

Hasil penelitian menunjukkan bahwa lebih dari separoh (60.7\%) ibu tidak memberikan ASI eksklusif pada bayi di Kelurahan Sawahan Wilayah Kerja Puskesmas Andalas Padang tahun 2017. Hasil penelitian ini sejalan dengan penelitian yang dilakukan oleh Tri Hartatik (2009) tentang hubungan tingkat pengetahuan ibu dengan pemberian ASI eksklusif di Kelurahan Gunungpati Kecamatan Gunungpati, menunjukan bahwa 64,3\% memiliki ibu tidak memberikan ASI eksklusif pada bayi mereka.

Hasil penelitian ini sejalan dengan penelitian yang dilakukan oleh (Hakim, 2012) tentang faktorfaktor yang berhubungan dengan pemberian ASI eksklusif pada bayi 7 - 12 bulan di Wilayah Kerja Puskesmas Nabira Kabupaten Nabire. Hasil penelitian menunjukkan hampir sebagian besar (70.2\%) ibu tidak memberikan ASI ekslusif pada bayi. 
Pemberian ASI eksklusif memberikan hanya ASI saja, berarti tidak diberi air putih, teh, minuman, ramuan, cairan lain, maupun makanan selama 6 bulan pertama usianya (Maryunani, 2015). ASI eksklusif merupakan bahan makanan pertama dan tunggal yang paling baik, paling sesuai dan paling sempurna bagi bayi, terutama pada saat-saat permulaan kehidupan (Yovita, dkk, 2011).

Ditemukan pada penelitian bahwa cukup banyak ibu yang tidak memberikan ASI eksklusif pada bayinya. Hal ini terlihat dari dari hasil kuesioner bahwa adanya pernyataan ibu yang tidak memberikan ASI saja sampai bayi berumur 6 bulan.

Padahal menurut Khasanah (2011) bahwa pemberian ASI eksklusif merupakan pemberian makanan bagi bayi selama 6 bulan tanpa tambahan cairan lain seperti susu formula, jeruk, madu, air teh, dan air putih, serta tanpa tambahan makanan padat seperti nasi tim, bubur susu, biskuit, dan pisang dan diberikan sampai bayi.

Arintasari (2015) menyatakan bahwa pemberian ASI merupakan salah satu upaya untuk mencapai pertumbuhan dan perkembangan yang optimal, karena memiliki nilai gizi yang tinggi dan melindungi bayi terhadap infeksi. Bayi yang mendapatkan ASI pada waktu lahir sampai 6 bulan akan terhindar dari infeksi.

Bayi yang tidak diberikan ASI eksklusif selama 13 minggu pertama dalam kehidupannya memiliki tingkat infeksi pernafasan dan infeksi saluran cerna yang lebih tinggi dibandingkan dengan bayi-bayi lain yang diberikan ASI eksklusif. Selain itu, bayi yang tidak diberikan ASI mudah terkena penyakitpenyakit lain yang berhubungan dengan kekebalan tubuh Fikawati, (2015).

Berdasarkan hal ini maka asumsi peneliti terhadap penelitian ini adalah ditemukan bahwa cukup banyak ibu yang tidak memberikan ASI eksklusif pada bayinya. Padahal ASI eksklusif sangat dibutuhkan oleh bayi untuk meningkatkan daya tahan tubuh bayi sehingga bayi tidak mudah terkena penyakit. Pada bayi yang tidak diberikan ASI eksklusif selama enam bulan akan beresiko terhadap terjadinya diare pada bayi dan bayi mudah terkena infeksi pernafasan dan infeksi saluran cerna.

\section{Pengetahuan Ibu}

Hasil penelitian menunjukkan bahwa lebih dari separoh $(55,7 \%)$ ibu berpengetahuan rendah di Kelurahan Sawahan Wilayah Kerja Puskesmas Andalas Padang tahun 2017. Hasil penelitian ini sejalan dengan penelitian yang dilakukan oleh Tri Hartatik (2009) tentang hubungan tingkat pengetahuan ibu dengan pemberian ASI eksklusif di Kelurahan Gunungpati Kecamatan Gunungpati, menunjukan dari 38 responden terdapat $17(44,7 \%)$ memiliki pengetahuan kurang baik tentang ASI eksklusif.

Hasil penelitian ini sejalan dengan penelitian yang dilakukan oleh (Hakim (2012) tentang faktor faktoryang berhubungan dengan pemberian ASI Esklusif pada bayi 7 - 12 bulan di Wilayah Kerja Puskesmas Nabira Kabupaten Nabire. Hasil penelitian menunjukkan sebagian $(50.0 \%)$ ibu berpengetahuan rendah tentang ASI eksklusif.

Pengetahuan adalah hasil pengindraan manusia, atau hasil tahu seseorang terhadap objek melalui indra yang dimilikinya (mata, hidung, telinga, dan sebagainya). Dengan sendirinya pada waktu pengindraan sehingga menghasilkan pengetahuan tersebut sangat dipengaruhi oleh intensitas perhatian dan persepsi terhadap objek. Sebagian besar pengetahuan seseorang diperoleh melalui indra pendengaran (telinga), dan indra penglihatan (mata) (Notoatmodjo, 2014).

Terlihat pada penelitian bahwa cukup banyaknya yang berpengetahuan rendah tentang ASI eksklusif. Hal ini terlihat dari hasil analisi kuesioner, dimana didapatkan data bahwa $78 \%$ ibu tidak tahu keuntungan pemberian ASI eksklusif terdapat 63\% ibu tidak tahu kapan sebaiknya ASI eksklusif diberikan terdapat $50 \%$ ibu tidak tahu tentang salah satu alasan penting pemberian ASI eksklusif terdapat, dan $47 \%$ ibu tidak tahu apa keunggulan bayi yang diberikan ASI eksklusif dibandingkan dengan bayi yang tidak mendapatkan ASI eksklusif.

Rendahnya pengetahuan ibu ini disebabkan karena kurangnya informasi yang didapatkan oleh ibu tentang ASI eksklusif. Sesuai dengan pendapat Notoatmodjo (2012) bahwa pengetahuan merupakan hal stimulasi informasi yang diperhatikan dan diingat. informasi tersebut bisa berasal dari pendidikan formal maupun nonformal, percakapan, membaca, mendengarkan televisi, dan pengalaman hidup. Contoh pengalaman hidup menyusui anak sebelumnya.

Berdasarkan hal ini maka asumsi peneliti terhadap penelitian ini adalah ditemukan bahwa cukup banyaknya ibu yang berpengetahuan rendah tentang ASI eksklusif. Hal ini menunjukkan masih kurangnya informasi yang didapatkan ibu tentang ASI eksklusif. Padahal pengetahuan ini sangat penting bagi ibu untuk dapat memberikan pengaruh terhadap pemberia ASI ekslusif oleh ibu terhadap bayi mereka.

\section{Tingkat Pendidikan Ibu}

Hasil penelitian menunjukkan bahwa sebagian besar $(77.0 \%)$ ibu mempunyai tingkat pendidikan rendah di Kelurahan Sawahan Wilayah Kerja Puskesmas Andalas Padang tahun 2017. Berbeda dengan penelitian yang dilakukan oleh Arintasari (2015) tentang faktor - faktor yang berhubungan dengan pemberian ASI eksklusif di Puskesmas Tegal Rejo Yogyakarta, menunjukkan bahwa $48.4 \%$ responden berpendidikan rendah.

Penelitian ini sejalan dengan penelitian yang dilakukan oleh (Hakim (2012) tentang faktor - 
faktor yang berhubungan dengan pemberian ASI eksklusif pada bayi $7-12$ bulan di Wilayah Kerja Puskesmas Nabira Kabupaten Nabire. Hasil penelitian menunjukkan sebagian $(50.0 \%)$ ibu berpendidikan rendah.

Pendidikan adalah suatu kegiatan atau proses pelajaran untuk mengembangkan atau meningkatkan pengetahuan tertentu sehingga sasaran pendidikan itu dapat berdiri sendiri. Wanita yang dikatakan tingkat pendidikannya Tinggi (DIII dan SI) dan rendah (SMP dan SMA) (Notoatmodjo, 2012).

Terlihat dari hasil penelitian bahwa sebagian ibu berpendidikan rendah. Hal ini terlihat dari hasil penelitian yaitu sebagian besar ibu yaitu sebanyak 46 orang $(75.4 \%)$ adalah tamatan SMA di Kelurahan Sawahan Wilayah Kerja Puskesmas Andalas Padang.

Menurut Hidayat (2008) bahwa jalur pendidikan adalah wahana yang dilalui oleh peserta didik untuk mengembangkan potensi diri dalam suatu proses pendidikan diri yang sesuai dengan tujuan pendidikan. Pendidikan formal merupakan pendidik yang diselenggarakan disekolah-sekolah pada umumnya jalur pendidikan ini mempunyai jalur pendidikan yang jelas, mulai dari pendidikan dasar, menengah, sampai pendidikan tinggi.

Pendidikan merupakan penuntun manusia untuk berbuat dan mengisi kehidupannya yang dapat digunakan untuk mendapatkan informasi sehingga dapat meningkatkan kualitas hidup. Sebagai mana umumnya semakin tinggi pendidikan seseorang makin mudah menerima informasi dan makin bagus pengetahuan yang dimiliki sehingga penggunaan komunikasi dapat secara efektif akan dapat dilakukannya ( Hidayat, 2008).

\section{Pekerjaan}

Hasil penelitian menunjukkan bahwa lebih dari separoh $(52,5 \%)$ ibu bekerja di Kelurahan Sawahan Wilayah Kerja Puskesmas Andalas Padang tahun 2017. Penelitian yang dilakukan oleh Ory Okawary (2015) dengan judul hubungan status pekerjaan ibu dengan pemberian ASI eksklusif di Wilayah Kerja Puskesmas Seyegan Slema Yogyakarta menunjukan dari 54 responden $24(44,4 \%)$ ibu yang meninggalkan bayinya.

Penelitian ini sejalan dengan penelitian yang dilakukan oleh (Hakim (2012) tentang faktor faktor yang berhubungan dengan pemberian ASI eksklusif pada bayi 7 - 12 bulan di Wilayah Kerja Puskesmas Nabira Kabupaten Nabire. Hasil penelitian menunjukkan lebih dari separoh $(66.3 \%)$ ibu bekerja.

Pekerjaan adalah suatu kegiatan yang dilakukan terutama untuk menunjang kehidupan keluarga. Pekerjaan bukanlah sumber kesenangan, tetapi lebih banyak merupakan cara mencari nafkah yang membosankan, berulang dan banyak tantangan. Sedangkan cara mencari nafkah yang membosankan, berulang dan banyak tantangan (Wawan \& Dewi, 2011).
Terlihat pada penelitian bahwa cukup banyak ibu yang bekerja. Hal ini menunjukkan karena tingginya tuntutan ekonomi keluarga sehinga mengharuskan ibu bayi untuk bekerja. Padahal menurut Roesli (2008). bekerja bukan alasan untuk menghentikan pemberian ASI secara eksklusif. Pada ibu yang bekerja, menyusui bayi tidak perlu dihentikan. Ibu yang bekerja tetap harus memberikan ASI kepada bayinya. Aktifitas ibu selama menyusui berpengaruh terhadap intensitas pertemuan ibu dan bayinya.

Bekerja umumnya merupakan kegiatan yang menyita waktu. Bekerja bagi seseorang akan mempunyai pengaruh terhadap kehidupan-kehidupan keluarga. Status pekerjaan diantaranya IRT, PNS, Wiraswasta dan pegawai swasta. Dalam penelitian ibu dikategorikan bekerja jika ibu meninggalkan bayi dan Tidak bekerja jika tidak meninggalkan bayi (Sudilarsih, 2009).

Berdasarkan hal ini maka asumsi peneliti terhadap penelitian ini adalah ditemukan cukup banyak ibu yang dinyatakan bekerja dalam hal ini diartikan ibu meninggalkan bayinya. Bekerjanya seorang ibu bayi mengindikasikan tingginya tuntutan ekonomi keluarga sehingga mengharuskan ibu untuk meninggalkan bayi mereka walaupun bayi masih membutuhkan ASI ekskusif sampai bayi berumur 6 bulan.

\section{B. Analisa Bivariat}

\section{Hubungan Pengetahuan Dengan Pemberian ASI Eksklusif}

Hasil penelitian menunjukkan bahwa proporsi ibu yang tidak memberikan ASI Ekskusif lebih banyak terdapat pada ibu yang berpengetahuan rendah yaitu sebanyak 25 orang $(73.5 \%)$ dibandingkan dengan ibu yang berpengetahuan tinggi yaitu sebanyak 12 orang (44.4\%). Hasil uji statistic (Chi square) diperoleh nilai $\mathrm{p}=0.041(p<0.05)$ maka dapat disimpulkan bahwa terdapat hubungan yang bermakna antara pengetahuan dengan pemberian ASI eksklusif di Kelurahan Sawahan Wilayah Kerja Puskesmas Andalas Padang tahun 2017.

Penelitian ini sejalan dengan penelitian yang dilakukan oleh Tri Hartatik (2009) dengan judul hubungan tingkat pengetahuan ibu dengan pemberian ASI eksklusif di Kelurahan Gunungpati Kecamatan Gunungpati. Hasil penelitian menunjukan bahwa ada hubungan pengetahuan dengan pemberian ASI eksklusif $(\mathrm{p}=0.034)$.

Penelitian ini sejalan dengan penelitian yang dilakukan oleh Hakim (2012) tentang faktor faktoryang berhubungan dengan pemberian ASI esklusif pada bayi 7 - 12 bulan di Wilayah Kerja Puskesmas Nabira Kabupaten Nabire. Hasil penelitian menunjukkan ada hubungan pengetahuan dengan pemberian ASI eksklusif ( $\mathrm{p}=0.000)$.

Terbukti pada penelitian bahwa adanya pengaruh pengetahuan terhadap pemberian ASI eksklusif pada bayi. Hal ini dapat disebabkan karena rendahnya pengetahuan ibu akan mempengaruhi terhadap 
pemahaman ibu dalam pemberian ASI eksklusif sehingga ibu cenderung tidak membeikan asi ekslusif pada bayi mereka.

Kementerian Kesehatan (2012) menyatakan bahwa penyebab faktor kurangnya pemberian ASI eksklusif adanya pengetahuan yang rendah tentang manfaat dan tujuan pemberian ASI eksklusif. Kemungkinan pada saat pemeriksaan kehamilan mereka tidak memperoleh penyuluhan intensif tentang ASI eksklusif, kandungan dan manfaat ASI, dan kerugian jika tidak memberikan ASI eksklusif.

Berdasarkan hal ini maka asumsi peneliti terhadap penelitian ini adalah ditemukan bahwa pengetahuan akan mempengaruhi terhadap pemberian ASI eksklusif pada bayi. Dimana jika ibu berpengetahuan tinggi akan cenderung untuk memberikan ASI eksklusif terhadap bayi mereka karena tingginya tingkat kesadaran ibu terhadap pentingnya memberikan ASI eksklusif pada bayi mereka dibandingkan dengan ibu yang berpengetahuan rendah.

Dengan demikian untuk meningkatkan pemberian ASI eksklusif pada bayi maka perlu adanya upaya peningkatan pengetahuan ibu tentang pentingnya pemberian ASI eksklusif pada bayi meliputi tentang manfaat ASI eksklusif, tujuan diberikan dan dampaknya jika tidak diberikan ASI eksklusif. Hal ini dapat dilakukan melalui penyuluhan intensif pada ibu pada saat pemeriksaan kehamilan tentang ASI eksklusif, kandungan dan manfaat ASI, dan kerugian jika tidak memberikan ASI eksklusif sehingga pengetahuan ibu meningkat menjadi lebih baik dan dapat meningkatkan pemberian ASI eksklusif pada bayi mereka.

\section{Hubungan Tingkat Pendidikan Dengan Pemberian ASI Eksklusif}

Hasil penelitian menunjukkan bahwa proporsi ibu yang tidak memberikan ASI Ekslusif lebih banyak terdapat pada ibu yang mempunyai tingkat pendidikan rendah yaitu sebanyak 33 orang $(70.2 \%)$ dibandingkan dengan ibu yang mempunyai tingkat pendidikan tinggi yaitu sebanyak 4 orang (28.6\%). Hasil uji statistic (chi square) diperoleh nilai $\mathrm{p}=$ $0.013(p<0.05)$ maka dapat disimpulkan bahwa terdapat hubungan yang bermakna antara tingkat pendidikan dengan pemberian ASI Eksklusif di Kelurahan Sawahan Wilayah Kerja Puskesmas Andalas Padang tahun 2017.

Penelitian ini sejalan dengan penelitian yang dilakukan oleh Arintasari (2015) tentang faktor faktor yang berhubungan dengan pemberian ASI Eksklusif di Puskesmas Tegal Rejo Yogyakarta. Hasil penelitian menunjukkan bahwa terdapat hubungan yang bermakna antara tingkat pendidikan dengan pemberian ASI Ekslusif $(\mathrm{p}=0,012)$.

Berbeda dengan penelitian yang dilakukan oleh Hakim (2012) tentang faktor - faktor yang berhubungan dengan pemberian ASI eksklusif pada bayi $6-12$ bulan di Wilayah Kerja Puskesmas Nabira Kabupaten Nabire. Hasil penelitian menunjukkan tidak ada pendidikan dengan pemberian ASI eksklusif ( $\mathrm{p}=0.733)$.

Terbukti pada penelitian bahwa tingkat pendidikan ibu akan mempengaruhi terhadap pemberian ASI eksklusif pada bayi. Hal ini dapat disebabkan karena rendahnya tingkat pendidikan ibu maka akan menghambat sikap terhadap nilai-nilai yang baru diperkenalkan, termasuk mengenai ASI eksklusif dibandingkan dengan ibu yang berpendidikan tinggi sehingga akan mempengaruhi terhadap kesadaran ibu dalam pemberian ASI eksklusif pada bayi mereka.

Sesuai dengan apa yang telah disampaikan oleh Kementerian Kesehatan (2012) bahwa penyebab faktor kurangnya pemberian ASI eksklusif salah satunya adalah faktor pendidikan, dimana makin tinggi pendidikan seseorang, maka makin mudah untuk menerima informasi sehingga semakin banyak pula pengetahuan yang dimiliki, sebaliknya pendidikan yang rendah akan menghambat sikap terhadap nilai-nilai yang baru diperkenalkan, termasuk mengenai ASI eksklusif.

Berdasarkan hal ini maka asumsi peneliti terhadap penelitian ini adalah terbukti bahwa tingkat pendidikan akan mempengaruhi terhadap pemberian ASI eksklusif pada bayi. Dimana ibu yang berpendidikan tinggi akan mempunyai kesadaran yang lebih tinggi dalam pemberian ASI eksklusif pada bayi mereka karena tingginya pemahaman ibu terhadap pentingnya pemberian Asi eksklusif pada bayi mereka sehingga meningkatkan kesadaran ibu dalam memberikan ASI eksklusif pada bayi mereka.

\section{Hubungan Pekerjaan Dengan Pemberian ASI Eksklusif}

Hasil penelitian menunjukkan bahwa proporsi ibu yang tidak memberikan ASI eksklusif lebih banyak terdapat pada ibu yang bekerja yaitu sebanyak 24 orang $(75.0 \%)$ dibandingkan dengan ibu yang tidak bekerja yaitu sebanyak 13 orang (44.8\%). Hasil uji statistik (chi square) diperoleh nilai $\mathrm{p}=0.032(p<$ 0.05) maka dapat disimpulkan bahwa terdapat hubungan yang bermakna antara tingkat pendidikan dengan pemberian ASI Eksklusif di Kelurahan Sawahan Wilayah Kerja Puskesmas Andalas Padang tahun 2017.

Penelitian ini sejalan dengan penelitian yang dilakukan oleh Ory Okawary (2015) dengan judul hubungan status pekerjaan ibu dengan pemberian ASI eksklusif di Wilayah Kerja Puskesmas Seyegan Slema Yogyakarta. Menunjukkan hasil bahwa ada hubungan pekerjaan dengan pemberian ASI eksklusif pada bayi $(\mathrm{p}=0,025)$.

Penelitian ini uga sejalan dengan penelitian yang dilakukan oleh Hakim (2012) tentang faktor - faktor yang berhubungan dengan pemberian ASI eksklusif pada bayi 7 - 12 bulan di Wilayah Kerja Puskesmas 
Nabira Kabupaten Nabire. Hasil penelitian menunjukkan ada hubungan pekerjaan dengan pemberian ASI eksklusif ( $\mathrm{p}=0.044)$.

Terbukti pada penelitian bahwa adanya pengaruh pekerjaan terhadap pemberian ASI eksklusif pada bayi mereka. Hal ini dapat disebabkan karena ibu bekerja maka waktu ibu bersama bayi akan berkurang sehingga ibu tidak biasa memberikan ASI eksklusif pada bayi mereka. Menurut Kementerian Kesehatan (2012), penyebab kurangnya cakupan pemberian ASI eksklusif adalah singkatnya masa cuti hamil atau melahirkan yaitu rata-rata hanya tiga bulan keterbatasan waktu atau kesibukan kerja, sehingga menyebabkan penggunaan susu botol atau susu formula diberikan pada bayi.

Menurut Notoatmodjo (2012) bahwa ketersediaan waktu seorang ibu untuk menyusui secara eksklusif berkaitan erat dengan status pekerjaannya. Banyak ibu yang tidak memberikan ASI eksklusif karena berbagai alasan, diantaranya karena harus kembali bekerja setelah melahirkan. Sehingga dalam memberikan ASI tidak lancar dikarenakan sibuk dengan kegiatan atau pekerjaan yang ia lakukan.

Padahal menurut Sudilarsi (2009), dalam masa menyusui, ibu yang bekerja tetap bisa memberikan ASI eksklusif untuk bayinya. Ibu bisa memerah ASI sebelum berangkat bekerja, kemudian di kantor, setiap minimal 3 jam sekali, perahlah satu payudara sekitar 3-5 menit sampai aliran ASI melambat. Setelah itu, perahlah payudara lainya. Sebelum memerah, lakukan pijat payudara agar produksi ASI lebih baik. Siklus pijat perah, perah dapat dilakukan berulang-berulang selama sekitar 20 menit sampai 1 jam. Patokan waktu ini bermanfaat bila ASI hanya keluar sedikit atau belum keluar sama sekali. Namun, jika patokan ASI sudah baik atau banyak, patokan tersebut bisa diabaikan. Ketika malam hari, setelah bayi kenyang menyusui, ibu juga bisa memerah ASI nya.

Berdasarkan hal ini maka menurut analisa peneliti terhadap penelitian ini adalah terbukti bahwa pekerjaan akan mempengaruhi terhadap pemberian ASI eksklusif pada bayi. Dimana pada ibu yang bekerja mereka cenderung tidak memberikan ASI eksklusif dengan alasan pekerjaan mereka. Padahal meskipun bekerja ibu tetap bisa memberikan ASI ekslusif dengan cara memerah payudara merekapada malam hari atau sebelum berangkat kerja sehingga ketersediaan ASI bisa terpenuhi untuk bayi. Dalam hal ini perlu adanya peran petugas kesehatan untuk memotivasi ibu yang bekerja untuk tetap memerikan ASI eksklusif ada bayi mereka melalui perahan payudara sehingga ketersediaan ASI untuk bayi dapat terpenuhi.

\section{KESIMPULAN}

\section{A. Kesimpulan}
1. Lebih dari separoh
$(60,7 \%)$ ibu tidak

memberikan ASI ekslusif pada bayi di Kelurahan Sawahan Wilayah Kerja Puskesmas Andalas Padang tahun 2017.

2. Lebih dari separoh $(55,7 \%)$ ibu berpengetahuan rendah di Kelurahan Sawahan Wilayah Kerja Puskesmas Andalas Padang tahun 2017.

3. Sebagian besar $(77,0 \%)$ ibu mempunyai tingkat pendidikan rendah di Kelurahan Sawahan Wilayah Kerja Puskesmas Andalas Padang tahun 2017.

4. Lebih dari separoh $(52,5 \%)$ ibu bekerja di Kelurahan Sawahan Wilayah Kerja Puskesmas Andalas Padang tahun 2017.

5. Terdapat hubungan yang bermakna antara pengetahuan dengan pemberian ASI Ekslusif di Kelurahan Sawahan Wilayah Kerja Puskesmas Andalas Padang tahun 2017 ( $\mathrm{p}=$ 0.041).

6. Terdapat hubungan yang bermakna antara tingkat pendidikan dengan pemberian ASI Ekslusif di Kelurahan Sawahan Wilayah Kerja Puskesmas Andalas Padang tahun 2017 $(\mathrm{p}=0.013)$.

7. Terdapat hubungan yang bermakna antara pekerjaan dengan pemberian ASI Ekslusif di Kelurahan Sawahan Wilayah Kerja Puskesmas Andalas Padang tahun 2017 (p = 0.032).

\section{B. Saran}

1. Bagi Petugas Puskesmas Andalas Padang Disarankan kepada pusat pelayanan kesehatan petugas puskesmas Andalas padang tidak mempromosikan susu formula, memberikan informasi yang tepat tentang ASI dan seputar kegiatan menyusui, serta memberikan semangat dan dorongan agar para ibu memberikan ASI eksklusif kepada bayi mereka.

2. Bagi Peneliti Selanjutnya

Saran untuk peneliti lain yang ingin melanjutkan penelitian ini adalah memperbanyak responden yang dijadikan sampel, melakukan penelitian di beberapa rumah Sakit sebagai perbandingan, dan memperdalam kualitas pelayanan pada kuesioner, sehingga hasilnya lebih akurat.

3. Bagi Institusi pendidikan

Diharapkan penelitian ini dapat dijadikan sumber referensi bacaan bagi pembaca dan dapat dijadikan informasi atau masukan bagi mahasiswa tentang ASI eksklusif.

\section{DAFTAR PUSTAKA}

Arikunto. 2006. Prosedur Penelitian Suatu Pendekatan Praktik. Jakarta : Rineka Cipta.

Arintasari. 2015. Faktor - Faktor Yang Berhubungan Dengan Pemberian ASI Ekslusif di Puskesmas 
Tegal Rejo Yogyakarta Tahun 2015. Jurnal Medika Respati vol.XI Nomor (2) April 2016.

Budiman \& Riyanto A. 2013. Kapita Selekta Kuesioner Pengetahuan dalam penelitian Kesehatan. Jakarta : Salemba Medika.

Depkes RI. 2012. Banyak sekali manfaat Asi bagi bayi dan ibu. Jakarta : Depkes RI.

Dinkes Kota Padang. 2015. Laporan Tahunan Cakupan Pemberian ASI Eksklusif tahun 2015. Padang : Dinas kesehatan Kota Padang.

Fikawati S, dan Syafik A. 2015. Gizi Ibu dan Bayi. Jakarta: Rajawali Pers.

Hakim. Faktor - Faktor yang Berhubungan Dengan Pemberian ASI Eksklusif pada bayi 6-12 bulan di Wilayah Kerja Puskesmas Nabira Kabupaten Nabire Kabupaten Nabira.

Hidayat, Aziz. 2008. Pengantar Ilmu Keperawatan Anak 1. Jakarta: Salemba Medika.

Imelda Rina, 2010. Panduan Kehamilan Dan Perawatan Bayi dari A-Z. Surabaya : Viktory

Irianto, Koes. 2014. Ilmu Kesehatan Anak ( Prediatri). Bandung : Alfabeta.

Kemenkes RI. 2015. Peringatan Pekan ASI Dunia.Jakarta : Kemenkes RI.

Kemenkes RI. 2012. PP peraturan pemerintah no 33 tahun 332012 tentang pemeberian air susu ibu eksklusif. Jakarta : Kementerian Kesehatan : 2012.
Mariam, Sity. 2016. Gizi Dalam Kesehatan Reproduksi. Jakarta selatan : Salemba Medika.

Maryunani, Anik. 2015. Inisiasi Menyusui Dini, ASI eksklusif dan Manajemen Laktasi. Jakarta : TIM

Notoatmodjo, S. 2012. Metodologi Penelitian Kesehatan. Jakarta: Rineka Cipta.

Notoatmodjo, S. 2014. Ilmu prilaku kesehatan. Jakarta: Rineka Cipta.

Ory, Okawary. 2015. Hubungan Status Pekerjaan Ibu Dengan Pemberian ASI Eksklusif di Wilayah Kerja Puskesmas Seyegan Slema. Yogyakarta Tahun 2015.

Profil Kesehatan Indonesia. 2015. Cukupan Pemberian ASI Eksklusif. Jakarta : Dinas Kesehatan Provinsi Sumatera Barat.

Sudilarsih, Feni. 2009. Buku pintar Dunia Bayi. Jogjakarta : Cara Ilmu.

Taylor, Johnson. 2005. Buku Ajar Praktik Kebidanan. Jakarta : EGC.

Tri, Hartatik. 2009. Hubungan Tingkat Pengetahuan Ibu Dengan Pemberian ASI Eksklusif di Kelurahan Gunungpati Kecamatan Gunungpati, Yogyakarta No (2) Desember 2009.

Wawan \& Dewi, 2011. Teori dan pengukuran pengetahuaan dan prilakumanusia. yogyakarta : Nuha Medika.

Yovita, 2011. Kehamilan dan Persalinan. Yogyakarta : $\quad$ EGC 